Reprod. Nutr. Dévelop., 1980, 20 (5 A), 1489-1501.

\title{
Reassessment of LRF radioimmunoassay in the plasma and hypothalamic extracts of rats and rams
}

\author{
par A. CARATY, Marie-Madeleine de REVIERS, J. PELLETIER, M. P. DUBOIS \\ Station de Physiologie de la Reproduction, I.N.R.A., \\ Nouzilly 37380 Monnaie, France.
}

\begin{abstract}
Summary. A highly sensitive and specific radioimmunoassay for LRF was applied to the measurement of endogenous LRF in various hypothalamic extracts. Specific antiserum was obtained by injecting LRF conjugated to human serum albumin with glutaraldehyde. Thyrotropin-releasing hormone, lysine vasopressin, oxytocin, noradrenaline, LH, FSH and cortical extracts did not appear to affect the assay, and the maximum cross-reaction observed with the LRF analogs fested was 8.5 p. 100 with LRF 2-10. The best detection limit ( $0.4 \mathrm{pg} /$ tube) was usually obtained when the labelled LRF had been purified by polyacrylamide gel electrophoresis. Within and between-assay coefficients of variation were 8.0 and 12.6 p. 100 , respectively (from $B / B o=20$ to 80 p. 100).

Synthetic LRF administered to rams by intravenous injection was readily detectable in the peripheral plasma. However, the direct measurement of plasma endogenous LRF may give misleading results due to non-specific interference by plasma factors. No endogenous LRF could be detected in plasma methanol or acetone extracts obtained from rats and rams in various physiological conditions.

The inhibition curves parallel to the synthetic LRF curve were obtained by diluting the crude hypothalamic extracts of rams and rats, and a good correlation $(r=0,997)$ with the Ramirez-McCann bioassay resulted, indicating that using radioimmunoassay to determine hypothalamic LRF content may be fruitful in studying hypothalamo-pituitary gonad interactions. The LRF content of rat and ovine hypothalami ranged from 2-8 to 20-80 $\mathrm{ng}$ of LRF, respectively.
\end{abstract}

\section{Introduction.}

Since the primary structure of LRF has been elucidated (Matsuo et al., 1971a) and subsequentially synthesized (Matsuo ef al., 1971b), many investigators have reported the development of LRF radioimmunoassays. However, the endogenous luteinizing hormone-releasing factor (LRF) levels measured under similar physiological conditions vary widely, even in the same species. For example, in five different publications these measurements in oestrous ewes range from less than 4 to $7000 \mathrm{pg} / \mathrm{ml}$ of plasma (Crighton ef al., 1973 ; Kerdelhué ef al., 1973 ; Jonas ef al., 1974 ; Nett et al., 1974 ; Nett and Adams, 1977).

On the other hand, Sarkar ef al. (1976) showed that preovulatory LH surge is caused by an increased LRF release in the pituitary stalk blood (50 to $150 \mathrm{pg} / \mathrm{ml}$ ). In the hypothalamo-pituitary system, the high LRF dilution, resulting from LRF secretion, 
produces a very low concentration $(<1 \mathrm{pg} / \mathrm{ml})$ in the peripheral blood. Therefore, in order to detect peripheral blood LRF levels, we have developed a highly specific and sensitive radioimmunoassay. This paper reports the difficulties inherent in this measurement, and compares the results of the Ramirez-McCann (1963) bioassay with ours evaluating the bioactive hypothalamic LRF content.

\section{Material and methods.}

1. Preparation of antiserum. - Synthetic LRF (Cytochemical, Los Angeles) was conjugated with human serum albumin by two methods, one using toluene diisocyanate as the coupling agent (Singer and Schick, 1961) and the other using glutaraldehyde (Dubois, 1976). The antisera were prepared by homogenizing the LRF conjugates with Freund's complete adjuvant and immunizing 4 rabbits (2/conjugate). The first injection was made into the spleen and each booster injection ( $400 \mu \mathrm{g}$ of LRF conjugated to $2000 \mu \mathrm{g}$ of HSA $/ 0.5 \mathrm{ml}$ of phosphate buffer $+0.5 \mathrm{ml}$ of adjuvant solution/injection/rabbit) was administered intradermally at about 40 sites or intravenously (without adjuvant). After a final intravenous booster injection (No 7), one antiserum, prepared with LRF-HSA-glutaraldehyde conjugate, could be used at a final dilution of 1:150 000 (B/T 50 p. 100)*.

2. Radioiodination of LRF. - LRF was iodinated using a modified chloramine $T$ technique (Greenwood ef al., 1963).

For that purpose, $7 \mu \mathrm{g}$ of LRF were dissolved in $7 \mu$ l of $0.5 \mathrm{M}$ phosphate buffer, $\mathrm{pH} 7.5$, and allowed to react at ambient temperature with $600 \mu \mathrm{Ci} \mathrm{Na}{ }^{125}$ (IMS 300, Radiochemical Center, Amersham, G. B.) for $20 \mathrm{sec}$ in the presence of $3.5 \mu \mathrm{g}$ of chloramine $T$ (total volume $20 \mu \mathrm{l}$ ). The reaction was stopped by adding $60 \mu \mathrm{g}$ of $\mathrm{Na}_{2} \mathrm{~S}_{2} \mathrm{O}_{5}$. After adding $500 \mu \mathrm{g}$ of $\mathrm{Kl}$, the mixture was transferred to a Sephadex LH-20 column $(1 \times 30 \mathrm{~cm})$ and eluted with a mixture of butanol-acetic acid-water $(40: 4: 8, \mathrm{v} / \mathrm{v})$. The fractions were collected $(1 \mathrm{ml})$, and the radioactivity was measured in a gamma counter. The fraction corresponding to maximum peptide radioactivity was dried under nitrogen, diluted and purified by polyacrylamide gel electrophoresis (Page),

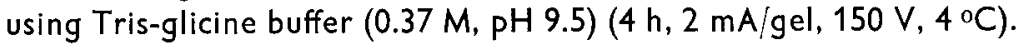

The concentration of acrylamide and bisacrylamide were 7.5 and 0.2 p. 100, respectively. Polymerization was obtained using ammonium persulphate (Hjerten et al., 1965). Before use, the gels were submitted to preliminary electrophoresis $(2 \mathrm{~h}, 2 \mathrm{~mA} /$ tube). The radioactive sample to be purified was introduced into a short vinyl tube forming the junction between two cylinders of gel. The advantages of this method, which we have perfected, are that different iodinated components can be identified, even if they migrate in opposite directions, and that the diffusion of ${ }^{125}$-LRF into the buffer solution is limited. After electrophoresis, the gels $(0.5 \times 3.2 \mathrm{~cm})$ were sliced transversely $(4 \mathrm{~mm})$; each slice was suspended in $1 \mathrm{ml}$ of electrophoretic buffer and left to diffuse at $4{ }^{\circ} \mathrm{C}$ for $2 \mathrm{hrs}$. Only one peak of radioactivity was found and used for radioimmunoassay. The unlabelled LRF was also subjected to Page under iden-

$* B=$ bound to antibody ; $T=$ total radioactivity. 
tical experimental conditions, and the Rf was determined by LRF radioimmunoassay in the diffusate or by staining with Pauly's reagent.

3. Characterization of the radioactive amino acid. - Aliquots of the iodinated LRF (after Page) were evaporated under a nitrogen stream and resuspended in $100 \mu \mathrm{l}$ of $0.01 \mathrm{~N} \mathrm{HCl}$. Five $\mu \mathrm{g}$ of pepsin (Sigma ref. 7000 from hog stomach mucosa) were added. After $24-\mathrm{hr}$ incubation at $37^{\circ} \mathrm{C}$, the contents of the tube were evaporated to dryness and resuspended in $50 \mu$ of 0.1 ammonium carbonate buffer ( $\mathrm{pH} 7.9$ ) containing 3-monoiodo-L-tyrosine (MIT, Sigma; $5 \mathrm{mg} / \mathrm{ml}$ ) and 3-5-diiodo-L-tyrosine (DIT, Sigma ; $5 \mathrm{mg} / \mathrm{ml}$ ) as carriers. Thin-layer chromatography of the digest was performed on silica gel plates (Merck No 5715) using the ethyl acetate system : methanol : $2 \mathrm{M} \mathrm{NH}_{4} \mathrm{OH} 5: 2: 1$. After development, the MIT and DIT standards were visualized with ninhydrin. The silica of the chromatogram of the digested ${ }^{125}$-LRF was aspirated from the zones corresponding to the MIT and DIT Rf's. The radioactivity of each zone was measured to obtain the relative ratio of MIT and DIT to monoiodinated and diiodinated LRF.

4. Radioimmunoassay (RIA). - To 100- $\mu$ l aliquots (in quadriplicate) of the standards or the samples in polystyrene tubes were added : (i) $50 \mu \mathrm{l}$ of antiserum diluted in barbitone buffer ( $125 \mathrm{mM}, 0.5$ p. 100 of HSA, pH 8.5) containing 1 p. 100 of intact rabbit serum and (ii) $350 \mu$ l of 125/-LRF (approx. $2500 \mathrm{cpm}$ ) diluted in barbitone buffer. The tubes were shaken briefly and incubated for 4 days at $4{ }^{\circ} \mathrm{C}$. Bound and free LRF were then separated by a double antibody method using $50 \mu \mathrm{l}$ of sheep anti-rabbit gamma globulin and 24-hr incubation at $4{ }^{\circ} \mathrm{C}$. After the addition of $2 \mathrm{ml}$ of barbitone buffer without human serum albumin, the tubes were centrifuged, the supernatant decanted, and the radioactivity in the precipitate counted for $5 \mathrm{~min}$.

5. Bioassay. - LRF bioassay was carried out in hypothalamic extracts according to Ramirez and MCCann (1963), and the results were expressed in plasma LH concentration 15 to $20 \mathrm{~min}$ after injection into oestrogen-progesterone-pretreated, ovariectomized rats. A double antibody RIA (NIAMDD kit) was used to determine plasma LH concentration, and the results were expressed in ferms of LH-RP ${ }_{1}$.

6. Animals. - We used the hypothalami of 120 -day old Wistar rat males (INRA strain 03) which were either intact or had been castrated 30 days beforehand. 40-day old Wistar rat females of the same strain were used as hypothalamic recipients for bioassay.

The hypothalami of 130-day old lle-de-France male lambs and 3-year old rams (either intact or castrated 1 year before) were also used. Intact or castrated adult rams and intact sows were also used for blood collection.

7. Hypothalamic extracts. - In both species, the hypothalamus, including the pars superior of the pituitary stalk, was collected immediately after rapid decapitation, homogenized in cold $0.1 \mathrm{~N} \mathrm{HCl}$, sonicated for $15 \mathrm{~min}$ at maximum power using a MSE $150 \mathrm{~W}$ ultrasonic disintegrator, then pooled with the other hypothalami and frozen. The limits of the hypothalamic samples were defined as the optic chiasma rostrally, the hypothalamic fissures laterally and the mammillary bodies posteriorly. Each hypothalamic section was approximately $2-3 \mathrm{~mm}$ in depth. Immediately before 
assay of LRF activity, the hypothalamic extracts were thawed, neutralized to $\mathrm{pH} 7$ with $1 \mathrm{~N} \mathrm{NaOH}$, centrifuged and the supernatant diluted as required.

8. Serum samples. - For LH RIA, blood samples were obtained from the jugular vein, allowed to clot for $4 \mathrm{hrs}$ at room temperature, centrifuged to obtain serum and frozen.

For LRF RIA, serum samples from animals injected with synthetic LRF were diluted and those from non-injected animals were extracted with methanol (Jeffcoate, 1974) or acetone (Neill et al., 1977).

\section{Results.}

1. lodination and labelled LRF binding to antiserum. - Figure 1 shows a typical pattern of radioactivity distribution after Sephadex $\mathrm{LH}-20$ filtration. Two peaks were eluted, the first (F18 to F28) contained ${ }^{125}$ I-LRF and presumably unlabelled LRF, and the second (F45 to F52) free ${ }^{125}$.

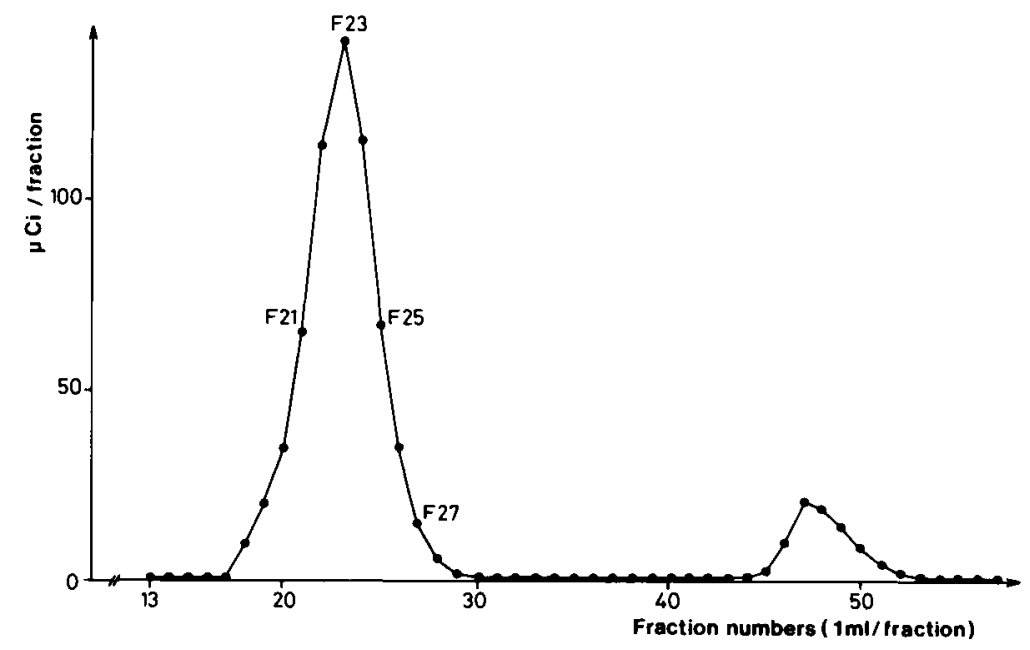

FIG. 1. - Distribution of radioactivity in a sephadex LH-20 column $(1 \times 30 \mathrm{~cm})$ eluted with butanol-acetic acid water $(40-4-8 \mathrm{v} / \mathrm{v})$.

The iodination yield was about 80 p. 100 . We used the difference in migration (at $\mathrm{pH} 9.5$, the unlabelled LRF moves faster towards the cathode than the 125|-LRF) during polyacrylamide gel electrophoresis to separate the ${ }^{125}$ |-LRF from the unlabelled LRF. After $3 \mathrm{hrs}$, the unlabelled LRF was eluted from the gel, while the ${ }^{125}$ |-LRF was still in the first $\mathrm{mm}$ of the gel. After $4 \mathrm{hrs}$ of electrophoresis, only 125/-LRF was found in the gel (fig. 2) and could be used for RIA. Before electrophoresis, binding to diluted antibody decreased strongly from the F21 to the F27 fractions (46 to 9 p. 100 ; fig. 3), whereas after electrophoresis, binding to antibody was about the same from F21 to 
F27, showing a maximum at F23 (52 p. 100). These discrepancies could be attributed to the increasing contamination of radioactive LRF by unlabelled hormone from F21 to F27. This is compatible with a partial LH-20 separation of 125I-LRF and LRF on a molecular weight basis. On the other hand, enzymatic degradation followed by chromatographic migration on silica gel showed only one spot of radioactivity which

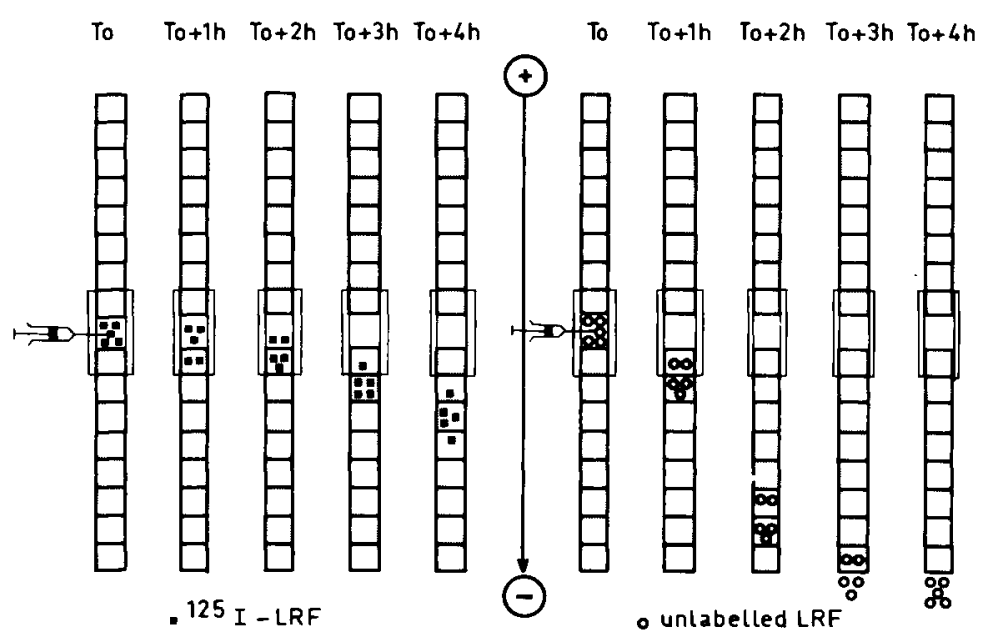

FIG. 2. - Migration of ${ }^{125 /-L R F(}(\mathbf{)})$ and unlabelled $\operatorname{LRF}(0)$ as a function of time during polyocrylamide gel electrophoresis. Samples were injected between two gels connected by a rubber tube.

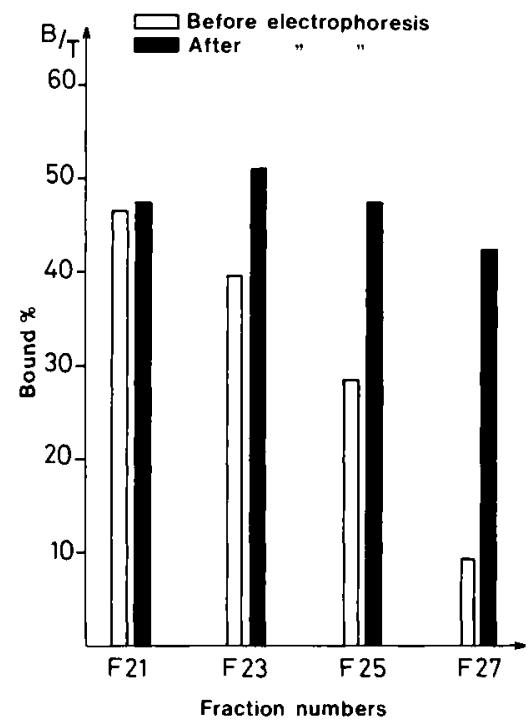

FIG. 3. - Percent of antiserum bound ${ }^{125}$ I-LRF of the same fractions from the first $L H-20$ peak (see fig. 1) before and after 4-hr electrophoresis (antiserum dilution : 1:150 000). 
coincided with the MIT Rf. This result demonstrated that LRF purified by LH-20 filtration and Page was monoiodinated LRF.

2. Sensitivity. - Figure 4 shows a standard curve obtained with the more active antiserum ( $N^{\circ} 8516$ ) at a final dilution of 1:150 000 (B/T 50 p. 100) and labelled LRF (F23 LH-20 fraction submitted to Page).

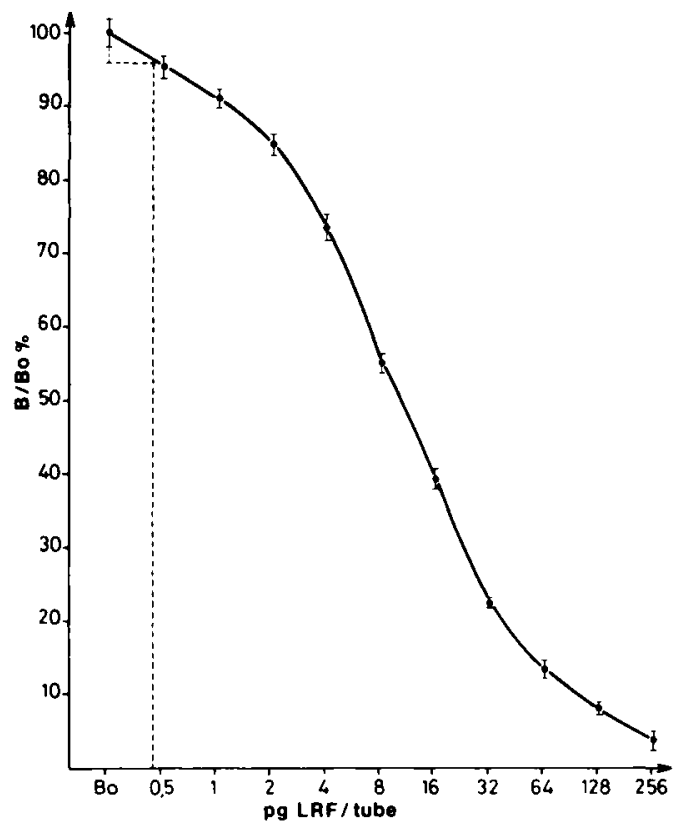

FIG. 4. - Displacemeril curve of LRF : points and vertical bars represent mean \pm standard deviation for 10 assays.

The maximal standard deviation of the various standard concentrations did not exceed 1.95 p. 100 . Thus, a 4 p. 100 decrease of bound radioactivity at the Bo level (approximately $2 \times$ the maximal standard deviation) defined the limit of the assay. Sensitivity, under the present conditions, was $0.4 \mathrm{pg} /$ tube.

3. Antiserum specificity. - Antiserum specificity was examined by testing the ability of pituitary hormones, hypothalamic extracts or synthetic peptides, including various LRF analogs, to inhibit $125 \mathrm{l}$-LRF binding to antibody. The results of these experiments (fig. 5) showed that the hypothalamic extract produced an inhibition curve parallel to that obtained with synthetic LRF. No inhibition could be observed with lysine vasopressin (100 pg-100 ng), LH (1 ng-100 ng), FSH (25 ng-200 ng), TRF (100 pg-100 ng), oxytocin (100 IU-100 mlU) or noradrenaline $(10 \mathrm{ng}-10 \mu \mathrm{g})$. Inhibition curves parallel to synthetic LRF were also obtained with LRF analogs but the percen- 


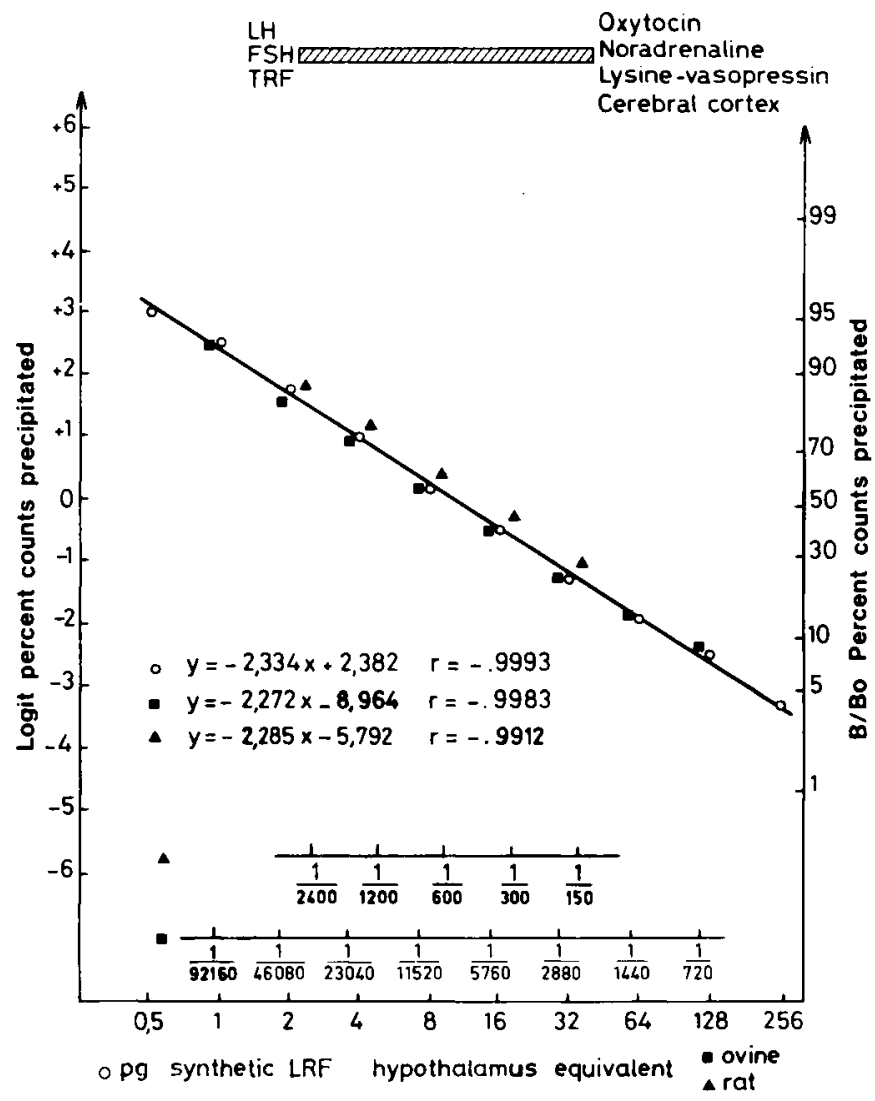

FIG. 5. - Inhibition curves to antibody obtained by adding increasing amounts of synthetic LRF, hypothalamic extracts, cerebral cortex extract, lysine-vasopressin, LH, FSH, TRF, oxytocyn, noradrenaline.

tage of cross-reaction (for $B / B \circ=50$ p. 100) was never higher than 9 p. 100 (table 1).

4. Precision and repeatability. - The mean variation coefficient for 8 hypothalamic extracts of four dilutions (B/Bo ranged from 20 to 80 p. 100) was 8 p. 100 within one assay.

The samples measured in 4 successive assays gave a variation coefficient of 12.6 p. 100.

5. Comparison of bioassay and RIA. - Figure 6 shows the dose-response curves in a Ramirez-McCann bioassay after injections of the synthetic LRF or the hypothalamic extracts of intact or castrated male rats. The responses were linear in the range of 1 to $10 \mathrm{ng}$ of synthetic LRF when expressed as a function of the log of the dose. The three curves were parallel, and their slopes differed from 0 (Snedecor, 1956). A similar experiment was realized with ram hypothalamic extracts (fig. 7). 
TABLE 1

Biological and immunological activity of LRF analogs

\begin{tabular}{|c|c|c|c|}
\hline Compound & Structure & $\begin{array}{c}\text { Biological } \\
\text { activity }\end{array}$ & $\begin{array}{c}\text { RIA } \\
\text { activity }\end{array}$ \\
\hline 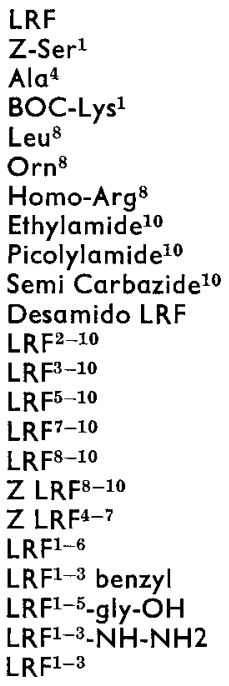 & 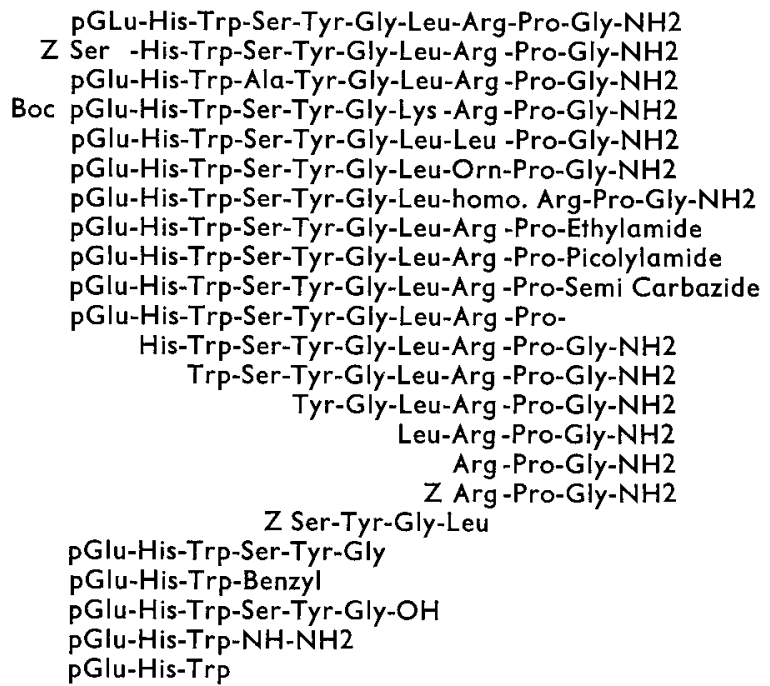 & $\begin{array}{c}100 \\
1 \\
5,8 \\
32 \\
1 \\
1,3 \\
5 \\
200 \\
1,4 \\
30 \\
0 \\
0,01 \\
0 \\
0 \\
0 \\
0 \\
0 \\
0 \\
0 \\
0 \\
0 \\
0 \\
0\end{array}$ & $\begin{array}{l}100 \\
6,4 \\
4,8 \\
2,4 \\
0 \\
0 \\
2,0 \\
0 \\
0 \\
0,8 \\
0 \\
8,5 \\
8,3 \\
0,4 \\
0 \\
0 \\
0 \\
0 \\
0 \\
0 \\
0 \\
0 \\
0\end{array}$ \\
\hline
\end{tabular}

$Z$ and $B O C$ are protective groups for chain lengthening.

Bioassay determinations measuring the plasma LH rise in ovariectomized, steroid-blocked rats wer performed by J. Sandow.

The analogs tested in the RIA ranged from 1 to $60 \mu \mathrm{g} /$ tube ; B/Bo activity =: $50 \mathrm{p} .100$.

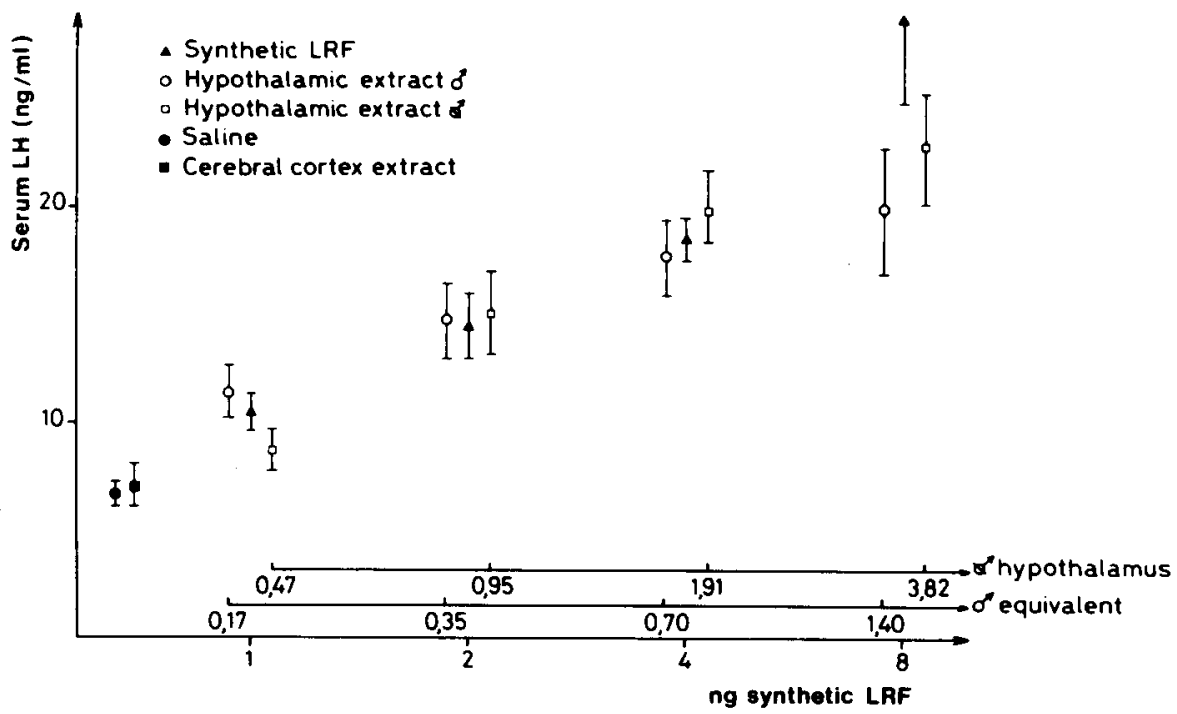

FIG. 6. - Dose-response curve $20 \mathrm{~min}$ after injection of serial dilutions of synthetic LRF or rat hypotholamic extracts. Points and vertical bars represent mean \pm standard deviation for 5 assays. 


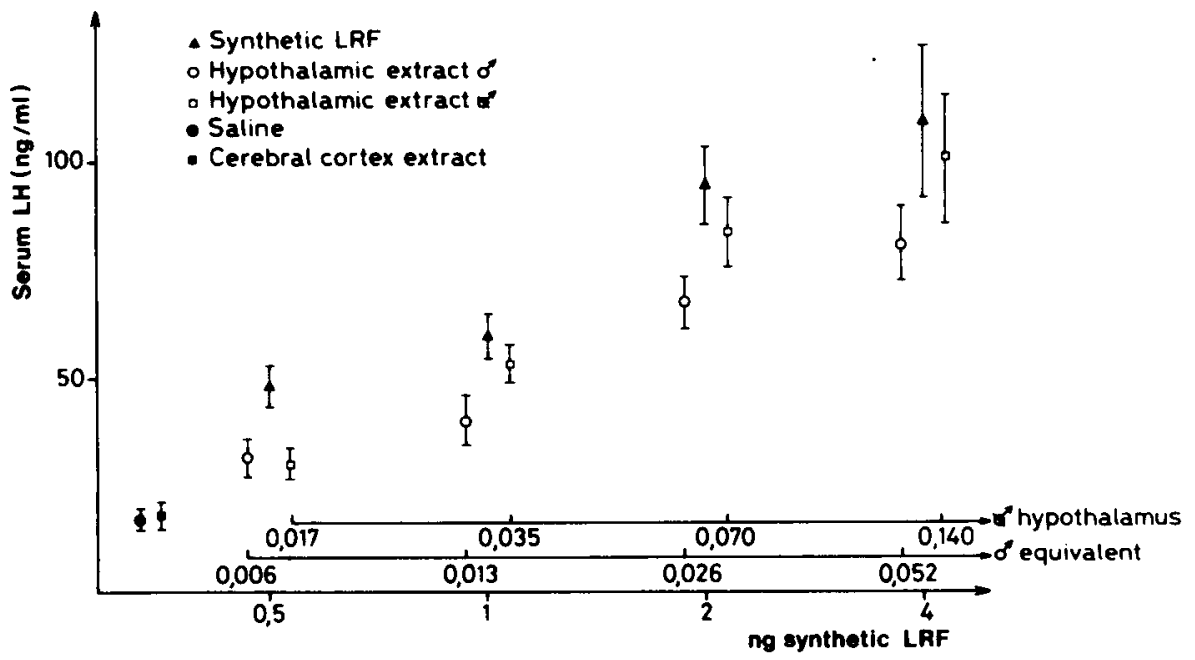

FIG. 7. - Dose response curve $15 \mathrm{~min}$ after injection of serial dilutions of synthetic LRF or ram hypothalamic extracts. Points and vertical bars represent mean \pm standard deviation for 6 assays.

These results gave the synthetic LRF value of each hypothalamus and permitted a comparison with those of the RIA (table 2). There was a high correlation $(r=0.997)$ between the estimates of LRF content by bioassay and RIA in the various hypothalamic extracts.

TABLE 2

Comparison of hypothalamic LRF contents in the same samples using RIA and the Ramirez-McCann bioassay

LRF content (ng/hypothalamus-equivalent) Biossoy RIA

\begin{tabular}{lccc}
\hline Intact male rat $\ldots \ldots \ldots \ldots \ldots$ & $6.13+1.41(5)$ & $6.16+0.14(4)$ \\
\hline Castrate male rat $\ldots \ldots \ldots \ldots \ldots$ & $2.20+0.32(5)$ & $2.13+0.07(4)$ \\
\hline Intact male ram $\ldots \ldots \ldots \ldots \ldots$ & $63.9+15.7(6)$ & $65.5+1.41(4)$ \\
\hline Castrate male ram $\ldots \ldots \ldots \ldots$ & $26.6+5.34(6)$ & $23.17+0.49(4)$
\end{tabular}

Results are expressed as ng + SEM (number of replicates).

$r=0.997$.

6. Measurement of plasma LRF. - $100 \mu \mathrm{g}$ of synthetic LRF injected intravenously were readily detectable in the peripheral plasma, and the curve of serial plasma dilutions was parallel to the standard curve at dilutions ranging from $1 / 30$ to $1 / 500$. On the other hand, increasing volumes of undiluted plasma without exogenous LRF produced a strong inhibition curve of ${ }^{125} \mid$-LRF binding to antibody. However, those 
curves were not parallel to the standard curve, and under all the conditions tested the non-specific binding to antibody was practically identical. This LRF-like material was partially destroyed after methanol or ethanol extraction when 80 to 90 p. 100 of the labelled or unlabelled exogenous LRF was recovered (table 3).

TABLE 3

Percentage of ${ }^{125} /$-LRF binding after addition of the same volume of a plasma sample before and after ethanol extraction

\begin{tabular}{lccccccc}
\hline B/Bo & $\begin{array}{c}\text { Intact } \\
\text { ram }\end{array}$ & $\begin{array}{c}\text { Castrate } \\
\text { ram }\end{array}$ & $\begin{array}{c}\text { Sow } \\
\text {-J8 œstrus }\end{array}$ & $\begin{array}{c}\text { Sow } \\
\text {-J4 œstrus }\end{array}$ & $\begin{array}{c}\text { Sow } \\
\text { œstrus }\end{array}$ & $\begin{array}{c}\text { Sow } \\
+\mathrm{J} 4 \text { œstrus }\end{array}$ & $\begin{array}{c}\text { Sow } \\
+\mathrm{J} 8 \text { œstrus }\end{array}$ \\
\hline $\begin{array}{l}\text { After addition of } 100 \mu l \\
\text { of unextracted plasma } \\
(\text { p. 100) } \ldots \ldots \ldots \ldots \ldots\end{array}$ & 58.3 & 57.4 & 56.8 & 56.9 & 59.9 & 61.1 & 60.7 \\
\hline $\begin{array}{l}\text { After addition of } 100 \mu l \\
\text { of ethanol equivalent } \\
\text { plasma extract (p. 100) }\end{array}$ & $>96$ & $>96$ & $>96$ & $>96$ & $>96$ & $>96$ & $>96$ \\
\hline
\end{tabular}

However, a new non-specific binding to antibody appeared when the extract of the large plasma sample was added into the tube $(B / B \circ=75$ p. 100 for $1 \mathrm{ml}$ of equivalent plasma extract), but it must be pointed out that methanol or ethanol extraction (measured by conductivity) allowed an 80 and 95 p. 100 recovery of salts and small molecules, respectively. On the other hand, the addition of $100 \mu \mathrm{l}$ of $1 \mathrm{M}$ sodium chloride or $100 \mu \mathrm{l}$ of medium 199 produced a decrease in binding to antibody $(\mathrm{B} / \mathrm{Bo}=90$ or 83 p. 100 , respectively).

\section{Discussion.}

In spite of the doubt expressed by Setalo et al. (1975), and already refuted by Dubois (1976), the present results clearly demonstrate that LRF conjugated to human serum albumin by glutaraldehyde is able to produce highly immunoreactive antisera against the whole molecule. Nett and Adams (1977) showed that the radioiodination and purification steps of 125 -LRF were important in obtaining the best sensitivity. In the present report, we have used a low concentration of the oxidizing agent $(0.5 \mu \mathrm{g} / \mathrm{\mu g}$ of LRF) and a low ratio of $\mathrm{Na}^{125}$-LRF $(0.006 \mu \mathrm{g} / \mu \mathrm{g}$ of LRF) to avoid altering the molecule and forming undesirable diiodo-LRF (Nett and Adams, 1977). These conditions produced a mixture of unlabelled LRF and 125 |-LRF. The two components were par. tially separated by LH-20 gel filtration, and further purified by polyacrylamide gel electrophoresis. The present data concerning the separation of ${ }^{125}$-LRF and unlabelled LRF agree with those of Miyachi ef al. (1973) and the work of Berson and Yalow (1966) who showed that anodal mobility of iodinated insulin increased progressively as the number of iodine atoms substituted in the molecule increased. Furthermore, the presence of only one peak of radioactivity after Page suggests the absence of a detectable dilodo-LRF contaminant; this is confirmed by chromatographic analysis on silica gel. These conditions may be related to assay sensitivity $(0.4 \mathrm{pg} /$ tube $)$, and are similar to the best procedures previously published (Jeffcoat, 1974 ; Nett and Adams, 1977). 
Oxytocin, noradrenaline, lysine-vasopressin, TRF, LH, FSH or cerebral cortex extract did not cross-react with antiserum. Therefore, this method can be considered as highly specific. The low cross-reactions observed with various LRF analogs indicate that the characterized antiserum is specific for the whole molecule and, in addition, that serial dilutions of crude extracts of lamb hypothalamus produce an inhibition curve parallel to that of synthetic LRF ; this would suggest that they contain a material which behaves immunologically as the entire decapeptide. The same result was obtained with hypothalamic extracts from various species such as rat, pig, horse and garden dormouse (unpublished results). The values of the LRF contents of ovine and rat hypothalamic extracts, obtained under different physiological conditions and measured by bioassay and RIA, were identical with both procedures. This finding again suggests that non-specific substances do not interfere in hypothalamic LRF RIA. The hypothalamic contents of normal adult male rats was approximately 6 to $8 \mathrm{ng}$. Those values agree with the data of Sandow and Heptner (1973) and Shin and Howitt (1974). Furthermore, the present paper reports an hypothalamic content of 60 to $80 \mathrm{ng}$ of LRF in the infact ram which is close to the values given for the ewe (Wheaton, 1976). In both species, castration was followed by a two to threefold decrease in hypothalamic LRF content ; such a decrease has been observed in the rat by Shin and Howitt (1975), Chen et al. (1977) and Badger et al. (1978).

However, we could not measure peripheral blood LRF using this specific, sensitive RIA for the following reasons :

1) LRF concentrations in hypothalamo-pituitary portal blood are reported to range from 10 to $500 \mathrm{pg} / \mathrm{ml}$ in rhesus monkeys (Carmel ef al., 1976), 10 to $50 \mathrm{pg} / \mathrm{ml}$ in rabbits (Tsou ef al., 1977) and 20 to $100 \mathrm{pg} / \mathrm{ml}$ in rats (Eskay ef al., 1975, 1977). Considering the dilution of the hypothalamo-pituitary portal blood in the peripheral circulation (500-fold in sheep; Nett ef al., 1974), peripheral blood LRF concentration. is well below the level of the present RIA sensitivity.

2) Methanol or acetone extraction destroys the immunoassayable LRF-like activity due to macromolecular components in the serum (de la Cruz and Arimura, 1975). However, in addition to protein effects, we have shown, in agreement with Berson and Yalow (1968), that salts or small molecules, concentrated during the procedure, may decrease total binding to antibody as has been reported for LRF RIA by Rotsziejn ef al. (1977). Therefore, the extraction of endogenous LRF from large plasma samples is limited by a high concentration of salts which must be separated from the LRF before RIA evaluation. This results in an additional step and presumably extra loss of LRF, incompatible with the low initial plasma level. Thus, we consider that the measurement of peripheral blood LRF needs further methodological improvement.

Reçu en mars 1979.

Accepté en ovril 1980.

Acknowledgements. - The authors express their gratitude to Dr. J. Sandow for supplying the various LRF analogs used in this study and wish to thank the NIAMDD rat pituitary hormone distribution program for the LH RIA kit. They also wish to thank Dr. Meredith Lemon for help in preparing the English manuscript and Miss Anne de le Dure for typing it. 
Résumé. Un dosage radioimmunologique du LRF hautement sensible et très spécifique est utilisé pour la mesure du contenu de divers extraits hypothalamiques. L'antisérum a été obtenu après injection du LRF couplé à la sérum albumine humaine par le glutaraldéhyde. Le TRF, la lysine-vasopressine, l'ocytocine, la noradrenaline, la LH, la FSH et des extraits corticaux n'interfèrent pas dans le dosage ef le maximum de réaction croisée observé avec les analogues testés est seulement de 8,5 p. 100 (pour le LRF 2-10). La meilleure sensibilité $(0,4 \mathrm{pg} /$ tube) est obtenue (habituellement) quand le LRF iodé est purifié sur gel de polyacrylamide. Les coefficients de variation intra et inter dosage sont respectivement de 8,0 p. 100 et 12,6 p. 100 (pour $B / B o$ de 20 à 80 p. 100). Le LRF synthétique administré à des béliers par voie intraveineuse est facilement détectable dans la circulation périphérique.

La mesure directe du LRF endogène du plasma circulant conduit à des résultałs erronés dus à des interférences non spécifiques de composants plasmatiques. Après extraction méthanolique ou acétonique de plasmas de rats ou de béliers dans divers conditions physiologiques, aucun LRF endogène n'a été détecté. Les extraits d'hypothalamus de rats et de béliers donnent des courbes d'inhibition parallèles à celles obtenues avec le LRF synthétique. Une bonne corrélation $(r=0,997)$ est obtenue entre les teneurs estimées par dosage radioimmunologique ou par le dosage biologique de Ramirez et McCann indiquant que l'estimation du contenu hypothalamique par dosage radioimmunologique est un bon moyen pour l'investigation des interactions, hypothalamus-hypophyse-gonades. Les contenus hypothalamiques de rats et de béliers varient entre (2 à 8$)$ et $(20$ à 80$)$ ng de LRF respectivement.

\section{References}

BADGER T. M., WILCOX C. E., MEYER E. R., BELL R. D., CICERO T. J., 1978. Simultaneous changes in tissue and serum levels of luteinizing hormone, follicle-stimulating hormone, and luteinizing hormone/follicle-stimulating hormone releasing factor after castration in the male rat. Endocrinology, 102, 136-141.

BERSON S. A., YALOW R. S., 1966. lodo-insulin used to determine specific activity of iodine 131. Science, 152, 205-206.

BERSON S. A., YALOW R. S., 1968. Radioimmunoassay of ACTH in plasma. J. clin. Invest., 47, 25-27.

CARMEL P. W., ARAKI S., FERIN M., 1976. Pituitary stalk portal blood collection in rhesus monkeys : evidence for pulsatile release of gonadofropin-releasing hormone. Endocrinology, 99, 243248.

CHEN H. T., GENEAU J., MEITES J., 1977. Effects of castration, steroid replacement and hypophysectomy on hypothalamic LH-RH and serum LH. Proc. Soc. exp. Biol. Med., 256, 127-131.

CRIGHTON D. B., FOSTER J. P., HOLLAND D. T., JEFFCOAT S. L., 1973. Simultaneous determination of $\mathrm{LH}$ and $\mathrm{LH}-\mathrm{RH}$ in the jugular venous blood of the sheep at œstrus. J. Endocr., 59, 373374.

DE LA CRUZ K. G., ARIMURA A., 1975. Evidence for the presence of immunoreactive plasma LH-RH which is unrelated to LH-RH decapeptide. Prog. 57th Annu. Meet. Endocr. Soc., New York (Abstr.), p. 103.

DUBOIS M. P., 1976. Immunological evidence of LH-RF in hypothalamus and medium eminence : A review. Ann. Biol. anim. Biochim. Biophys., 16, 177-194.

ESKAY R. L., WARBERG J., MICAL R. S., PORTER J. C., 1975. Prostaglandin $E_{2}$-induced release of LH-RH into hypophyseal portal blood. Endocrinology, 97, 816-824.

ESKAY R. L., MICAL R. S., PORTER J. C., 1977. Relationship between luteinizing hormone releasing hormone concentration in hypophysial portal blood and lufeinizing hormone release in intact, castrated and electrochemically-stimulated rats. Endocrinology, 100, 263-269.

GREENWOOD F. C., HUNTER W. H., GLOVER J. S., 1963. The preparation of 131 I - labelled human growth hormone of high specific radioactivity. Biochem. J., 89, 114-123.

HJERTEN S., JERSTED S., TISELIUS A., 1965 . Electrophoretic « particle sieving » in polyacrylamide gels as applied to ribosomes. Anaiyt. Biochem., II, 211-218. 
JEFFCOATE S. L., 1976. Problems with the assay of LH-RH in biological fluids. Ann. Biol. anim. Bioch. Biophys., 16, 195-204.

JONAS H. A., BURGER H. G., CUMMING I. A., FINDLAY J. K., de KREISER D. M., 1975. Radioimmunoassay for luteinizing hormone-releasing hormone (LH-RH) : its application to the measurement of LH-RH in ovine and human plasma. Endocrinology, 96, 384-393.

KERDELHUÉ B., JUTISZ M., GILLESEN D., STUDER R. O., 1973. Obtention of antisera against the hypothalamic decapeptide LH-RH and development of its radioimmunoassay. Biochim. biophys. Acto, 297, 540-548.

MATSUO H., BABA V., NAIR R. M. G., ARIMURA A., SCHALLY A. V., 1971a. Structure of the porcine LH and FSH-releasing hormone. I. The proposed amino-acid sequence. Biochim. biophys. Res. Commun., 43, 1334-1339.

MATSUO H., ARIMURA A., NAIR R. M. G., SCHALLY A. V., 1971b. Synthesis of the porcine LH and FSH-releasing hormone by the solid phase method. Biochem. biophys. Res. Commun., 45, 822-828.

MIYACHI Y., CHRAMBACH A., MECKLENBURG R., LIPSETT M. B., 1973. Preparation and properties of 125I-LH-RH. Endocrinology, 92, 1725-1730.

NEILL J. D., PATTON J. M., DAILEY R. A., TSOU R. C., TINDALL G. T., 1977. Luteinizing hormone releasing hormone in pituitary stalk blood of rhesus monkeys : relationship to level of $\mathrm{LH}$ release. Endocrinology, 101, 430-434.

NETT T. M., ADAMS T. E., 1977. Further studies on the radioimmunoassay of gonadotropin-releasing hormone : effect of radioiodination, antiserum and unextracted serum on levels of immunoreactivity in serum. Endocrinology, 101, 1135-1144.

NETT T. M., AKBAR A. M., NISWENDER G. D., 1974. Serum levels of LH and GnRH in cycling, castrated and anestrous ewes. Endocrinology, 94, 713-719.

RAMIREZ V. D., McCANN S. M., 1963. A highly sensitive test for LH-releasing activity : the ovariectomized, estrogen-progesterone-blocked rat. Endocrinology, 73, 193-198.

ROTSZTEJN W. H., CHARLI J. L., PATTOU E., KORDON C., 1977. Stimulation by dopamine of luteinizing hormone-releasing hormone (LH-RH) release from the mediobasal hypothalamus in male rats. Endocrinology, 101, 1475-1483.

SANDOW J., HEPTNER W., 1973. Hypothalamic content of LH-RH in male and female rats before puberty and during reproductive life. Acta endocr. Suppl. 177, 76.

SARKAR D. K., CHIAPPA S. A., FINK G., SHERWOOD N. M., 1976. Gonadolropin-releasing hormone surge in pro-œstrous rats. Nature, 264, 461-463.

SETALO G., VIGH S., SCHALLY A. V., ARIMURA A., FLERKO B., 1975. LH-RH containing neural elements in the rat hypothalamus. Endocrinology, 96, 135-142.

SHIN S. H., HOWITT C. J., 1974. Acidic aqueous extraction of hypothalamic luteinizing releasing hormone to study biological effects. Can. J. Physiol. Phormocol., 52, 754-758.

SHIN S. H., HOWITT C., 1975. Effect of castration on luteinizing hormone and luteinizing hormone releasing hormone in the male rat. J. Endocr., 65, 447-448.

SNEDECOR G. W., 1956. Statistical methods. The lowa State Univ. Press. 5th éd.

SINGER S. J., SCHICK A. F., 1961. The properties of specific stains for electron microscopy prepared by the conjugation of antibody molecules with ferritin. J. biophys. biochem. Cyfol., 9, 519-537.

TSOU R. C., DAILEY R. A., MCLANAHAN C. S., PARENT A. D., TINDALL G. T., NEILL J. D., 1977. Luteinizing hormone releasing hormone levels in pifuitary stalk plasma during the preovulatory gonadotropin surge of rabbits. Endocrinology, 101, 534-539.

WHEATON J. W., 1976. Regional brain content of luteinizing hormonereleasing hormone during anestrus and the estrous cycle of sheep. Fed. Proc., 35, 700. 